\title{
P325: Evaluation of rational prescribing of essential generic drugs in a rural community in Mali
}

\author{
M Sanogo $^{1 *}$, S Maiga ${ }^{2}$, B Koumare ${ }^{2}$, OS Maiga ${ }^{2}$ \\ From 2nd International Conference on Prevention and Infection Control (ICPIC 2013) \\ Geneva, Switzerland. 25-28 June 2013
}

\section{Objectives}

To assess the quality of the prescription of generic essential drugs in a reference health center in Mali.

\section{Methods}

This is a descriptive cross-sectional study which was conducted from March to December 2008. The sample consisted of 300 prescriptions in outpatient. The parameters studied were the reasons for consultation, diagnosis retained, prescription drugs, and information on training for prescribers, standards and the treatment regimen.

\section{Results}

There were 1036 drugs prescribed for 300 prescriptions. Drugs most prescribed were anti-infectives, then analgesics, antipyretics and antimalarials. The average number of drugs per prescription was 3.4 . In $70 \%$ of prescriptions generics were prescribed, doctors were prescribers for only $64 \%$ of prescriptions. The average number of brand-name medicines per prescription was 1.03 . The percentage of orders that contained at least one brand-name medicine was $62.33 \%$. Influencing factors evoked by prescribers were: efficiency for $57.9 \%$, the cost $(31.6 \%)$ and the availability (10.5\%). The mean cost of the order was 4400 CFA francs (about seven euros).

\section{Conclusion}

Brand names continue to be widely prescribed in the rural town of San. A medicine prescription of international nonproprietary names is highly recommended.

\section{Disclosure of interest}

None declared.

'Faculty of Medicine, School of Public Health, University of Montreal, Montreal, Canada

Full list of author information is available at the end of the article

\section{Author details}

${ }^{1}$ Faculty of Medicine, School of Public Health, University of Montreal, Montreal, Canada. 'Faculty of Medicine, Pharmacy and Dentistry, Bamako, Mali.

Published: 20 June 2013

doi:10.1186/2047-2994-2-S1-P325

Cite this article as: Sanogo et al.: P325: Evaluation of rational prescribing of essential generic drugs in a rural community in Mali. Antimicrobial Resistance and Infection Control 2013 2(Suppl 1):P325.
Submit your next manuscript to BioMed Central and take full advantage of:

- Convenient online submission

- Thorough peer review

- No space constraints or color figure charges

- Immediate publication on acceptance

- Inclusion in PubMed, CAS, Scopus and Google Scholar

- Research which is freely available for redistribution
C Biomed Central

\section{Biomed Central}

